\title{
Delayed-Interval Delivery in Dichorionic Twin Pregnancies: A Case Report of 154 Latency Days
}

\section{Parto diferido em gravidez gemelar bicoriônica: Um caso com 154 dias de latência}

\author{
Catarina Alexandra Soares de Frias ${ }^{1}$ Alexandra Sofia Puga Alvarez de Faria Queirós $^{2}{ }^{\circledR 0}$ \\ Helena Teresinha Fernandes Simões ${ }^{2(1)}$
}

${ }^{1}$ Department of Obstetrics and Gynecology, Hospital do Divino

Espírito Santo, Ponta Delgada, São Miguel, Açores, Portugal

2 Department of Obstetrics and Gynecology, Maternidade Dr. Alfredo da

Costa, Centro Hospitalar Universitário Lisboa Central, Lisboa, Portugal
Address for correspondence Catarina Alexandra Soares De Frias, MD, Hospital do Divino Espírito Santo, Avenida D. Manuel I, 9500-370, Ponta Delgada, São Miguel, Açores, Portugal
(e-mail: catarinasoaresfrias@gmail.com).

Rev Bras Ginecol Obstet 2020;42:61-64.

\section{Abstract \\ Keywords \\ - delayed-interval delivery \\ - twin pregnancy \\ - preterm birth \\ - maternal morbidity \\ - neonatal morbidity}

\section{Resumo}

received

August 21, 2019

accepted

November 25, 2019
Premature delivery often complicates multifetal pregnancies, placing neonates at risk of serious morbidity and mortality. In select cases, preterm birth of one sibling may not require delivery of the remaining fetus(es), which may remain in utero for a delayedinterval delivery, consequently improving neonatal morbidity and mortality. Currently, there is no consensus on the best protocol for the optimal management of these cases. We report one case of delayed-interval delivery of a dichorionic pregnancy assisted in our center. In this case, prophylactic cerclage, tocolytic therapy and administration of broad-spectrum prophylactic antibiotics enabled delivery at 37 weeks, corresponding to 154 days of latency, which is, to our knowledge, the longest interval described in the literature. The attempt to defer the delivery of the second fetus in peri-viability is an option that should be offered to parents after counseling, providing that the clinical criteria of eligibility are fulfilled. The correct selection of candidates, combined with the correct performance of procedures, as well as fetal and maternal monitoring and early identification of complications increase the probability of success of this type of delivery.

O parto pré-termo espontâneo complica frequentemente as gestações multifetais, condicionando elevada morbimortalidade perinatal. Em determinados casos, o nascimento prematuro do primeiro feto pode não requerer o nascimento do(s) feto(s) restante(s), que podem permanecer in utero, com o objetivo de diminuir a morbidade e mortalidade neonatal. Atualmente, não existe consenso quanto à melhor atitude clínica nas situações de parto diferido. Descrevemos um caso de parto diferido de gravidez bicoriônica vigiado no nosso centro. Neste caso, a realização de cerclagem, a terapêutica tocolítica e a administração de antibioticoterapia de largo espectro permitiu o parto às 37 semanas do segundo gêmeo, o que corresponde a 154 dias de latência, que, segundo o nosso conhecimento, é o intervalo de diferimento mais 
Palavras-chave

- Parto diferido

- Gravidez gemelar

- Parto pré-termo

- Morbidade materna

- Morbidade neonatal longo descrito na literatura. A tentativa de diferir o parto do segundo feto na periviabilidade é uma opção que deve ser oferecida aos progenitores, após aconseIhamento e desde que se cumpram os critérios clínicos de elegibilidade. A seleção correta das candidatas, em conjunto com a realização de corretos procedimentos, monitorização fetal e materna e identificação precoce de complicações aumentam a possibilidade de sucesso deste tipo de parto.

\section{Introduction}

In the last decades, multifetal pregnancies have been increasing as a result of a higher mean maternal age and increased use of assisted reproductive technologies. ${ }^{1-4}$ As a result, there is a high risk of preterm premature rupture of membranes and preterm delivery, placing neonates at risk of serious morbidity and mortality. ${ }^{1,2}$ In twin pregnancies, delivery of the second twin generally follows the birth of the first fetus shortly thereafter. However, in selected cases, preterm birth of one sibling may not require delivery of the remaining fetus(es), who may remain in utero for an extended period. This event is defined as a delayed delivery of the second twin, and has been reported as a management strategy to decrease morbidity and optimize the survival of the remaining fetuses after the spontaneous preterm birth of one fetus during a multifetal gestation. ${ }^{1,5,6}$ Despite the interest in this subject, in the literature there is still a lack of an universally-accepted protocol for the optimal management of these cases. ${ }^{1-3,7,8}$ Here, we report the results of one dichorionic pregnancy with a delayed delivery of 154 days assisted at our center.

\section{Case Report}

A 33 year-old healthy woman, with 2 previous late abortions, was followed in our institution due to a dichorionic twin pregnancy. She had two embryo transfers after a successful assisted reproductive technology (ART) cycle. She was admitted to our emergency department at 15 weeks due to regular contractions. During the pelvic examination, bulging membranes and a complete cervical dilatation was observed, with subsequent en caul delivery of the presenting fetus. After the delivery of the first twin, the uterine contractions ceased. There were no signs of chorioamnionitis. The amniotic membrane of the second twin remained intact, and ultrasonography showed a healthy remaining fetus. The parents were informed about the option of deferring delivery of the remaining fetus along with its benefits and possible complications for the mother and remaining fetus. After the parents decided to defer the delivery of the remaining fetus, cervical cultures were taken, and a McDonald cerclage was performed under general anesthesia. Tocolysis with $25 \mathrm{mg}$ of indomethacin was administered 4 times a day for 2 days, and broad-spectrum antibiotics (ampicillin and gentamycin) were administered for 7 days. The mother was continuously monitored through clinical assessment and laboratory tests. No signs of infection were listed, and serial ultrasonography confirmed fetal growth and wellbeing.
The cervical length was monitored weekly with transperineal ultrasonography. Due to maternal and fetal stability, the patient was discharged at the 17 th week of pregnancy. A transperineal ultrasound revealed a stable cervix, with $21 \mathrm{~mm}$ in length. The remaining pregnancy was as expected. At the 37th week, the cervical cerclage suture was removed. And at 37 weeks and 1 day, 154 days after the delivery of the first fetus, the remaining fetus was delivered vaginally. The second baby weighed 2,980 g, and the Apgar score was 9 at the 1 st minute, and 10 at the 5 th minute. No maternal morbidity occurred after the delivery, and the baby girl had an uneventful neonatal course.

\section{Discussion}

Delayed-interval delivery was first reported in the 1960s as a means of prolonging pregnancy for multifetal gestations after spontaneous delivery of the first fetus. ${ }^{6,9}$ Since then, several case reports of asynchronous delivery have been published. To our knowledge, the published case with the longest interval between the births of both twins was also 154 days. $^{10}$ This prolongation of the gestational period enables the reduction of premature and neonatal morbidity, and increases the survival rate of the remaining fetus. ${ }^{1,7,10,11}$ Consistent with this, Van der Straeten et al ${ }^{12}$ reported a decrease of $13.4 \%$ in mortality with a delayed delivery of the second fetus. ${ }^{2,12}$ It is essential that a number of conditions for deferred delivery of the second fetus are present: multifetal gestation with delivery of the first fetus before the 30th week, diamniotic pregnancy, intact membranes in the remaining gestational sac, and absence of fetal or maternal indication for delivery. ${ }^{2,7,11,13}$ These inclusion criteria were all fulfilled in our case. The optimal management for a delayed-interval delivery has not yet been defined. Cerclage, tocolysis, hospitalization, and antibiotic therapy are all still controversial procedures. $1,2,7-9,13$

The use of prophylactic cerclage is the most controversial issue among the recommended procedures. $7,8,11,13,14$ For some authors, it is a routine procedure, while for others it is recommended only if the etiology of the spontaneous delivery is cervical insuffiency. ${ }^{7,8,11}$ Zhang et $\mathrm{al}^{15}$ concluded that in cases of delayed-interval delivery, immediate cervical cerclage after the first delivery is associated with a significantly longer delivery interval between twins without increasing the rate of intrauterine infection. ${ }^{2,10,15}$ The median interdelivery interval was 8 and 25 days in patients without and with cervical cerclage respectively. ${ }^{10}$ Cerclage can minimize the exposure 
of the fetal membranes to vaginal bacteria, and may provide stability to the cervix. ${ }^{2}$ In our case, we performed a cervical cerclage and no intrauterine infection was detected. The use and duration of the tocolysis in cases of asynchronous delivery are not well established. ${ }^{11}$ Some authors recommend routine tocolysis after the birth of the first twin, until the contractions cease. ${ }^{713}$ Others use tocolytic therapy even if there is no contractility, in cases of the performance of cerclage. In these cases, a course of 48 hours of tocolytic therapy may curb the uterine contractions precipitated by the cervical manipulation. ${ }^{16}$ Furthermore, studies demonstrate that the perinatal results in situations of threatened labor are not better when tocolysis are used as a maintenance therapy, or with repeated courses of tocolysis. ${ }^{11}$ Because of that, tocolysis with indomethacin was performed 48 hours after the prophylactic cerclage. Some authors advocate strict bed rest in the hospital until the delayed delivery. Others believe that a prolonged hospitalization is not necessary. Up to now, no management has proved to be superior to the other. ${ }^{7,13,17,18}$ In the case herein reported, given the maternal and fetal stability, the patient was discharged.

We opted for broad-spectrum prophylactic antibiotics, which are routinely administered by most authors to prevent the onset of an infection. ${ }^{7,9,11}$ There is no consensus about the antibiotics of choice, the duration of the treatment, and the route of administration. However, the therapeutic scheme used in situations of preterm premature rupture of membranes could be extrapolated to cases of asynchronous delivery, because the infectious agents are similar. ${ }^{11}$ In addition to protecting against infections, antibiotics often have tocolytic properties. ${ }^{7,9}$ Given the cervical stability, no steroid therapy was administered at 24 weeks. Most studies demonstrate that maternal morbidity associated with asynchronous delivery is rare. ${ }^{9}$ However, some authors describe a considerable incidence of serious maternal morbidity due to intrauterine sepsis and septicemia. ${ }^{6,7}$ Careful monitoring can prevent the more serious maternal risks. We do not report any maternal complication. Neonatal survival and morbidity are primarily dependent on gestational age at birth. ${ }^{6,7}$ Different clinical centers describe different survival rates, which range from $29 \%$ to $82 \%{ }^{10}$ The long-term outcome and neurological development seems to be comparable to those of children with the same gestational age. ${ }^{9,19}$ In the case reported here, the fetal short-term outcomes were optimal, with no neonatal morbidity.

In conclusion, delayed-interval delivery is a useful and possible therapeutic option for the management of the remaining fetus, enabling the improvement of neonatal survival and decreasing morbidity. ${ }^{1,5,6}$ Selecting optimal candidates for delayed-interval delivery is fundamental, and parents should always be counseled about the potential risks and benefits of the procedure. ${ }^{6,11,20,21}$ Further research in this field is needed to generate standardized management guidelines for the deferred delivery. ${ }^{1-3,7,8}$ In the case herein reported, the performance of prophylactic cerclage, a short course of tocolytic therapy, and the administration of broad-spectrum prophylactic antibiotics enabled the delivery of the second fetus at 37 weeks, corresponding to 154 days of latency.
Conflict of Interests

The authors have no conflict of interests to declare.

\section{References}

1 Galvão A, Gonçalves D, Rocha A, Rodrigues A, Buchner IG, Cunha A, Braga J. Delayed interval delivery of a second twin resulting in septic shock in the mother. Nascer Crescer. 2016;25(4):241-243

2 Aydin Y, Celiloglu M. Delayed interval delivery of a second twin after the preterm labor of the first one in twin pregnancies: delayed delivery in twin pregnancies. Case Rep Obstet Gynecol. 2012;2012:573824. doi: 10.1155/2012/573824

3 Arabin B, van Eyck J. Delayed-interval delivery in twin and triplet pregnancies: 17 years of experience in 1 perinatal center. Am J Obstet Gynecol. 2009;200(2):154.e1-154.e8. doi: 10.1016/j. ajog.2008.08.046

4 Văduva CC, Constantinescu C, Țenovici M, Văduva AR, Niculescu $\mathrm{M}$, DiȚescu D, et al. Delayed interval delivery in twin pregnancy case reports. Rom J Morphol Embryol. 2016;57(3):1089-1098

5 The Royal Women's Hospital. Multiple pregnancy - interval birth delivery: clinical guideline. Melbourne: The Royal Women's Hospital; 2019

6 Roman AS, Fishman S, Fox N, Klauser C, Saltzman D, Rebarber A. Maternal and neonatal outcomes after delayed-interval delivery of multifetal pregnancies. Am J Perinatol. 2011;28(2):91-96. doi: 10.1055/s-0030-1262513

7 Raposo MI, Cardoso M, Ormonde M, Stokreef S, Correia L, Pereira A. Obstetric management of delayed-interval delivery. Case Rep Womens Health. 2017;16:11-13. doi: 10.1016/j.crwh.2017.09.002

8 Zorilă GL, Marinaş MC, Florea M, Pătru CL, Drăguşin RC, Căpitănescu RG, et al. Stillbirth in dichorionic twins discordant for major and minor anomaly, followed by asynchronous delivery - a rare occurrence. Case presentation. Rom J Morphol Embryol. 2016;57 (3):1117-1123.

9 Yodoshi T, Tipton E, Rouse CA. A case of delayed interval delivery with a successful hospital move. Case Rep Pediatr. 2015; 2015:802097. doi: 10.1155/2015/802097

10 Benito Vielba M, De Bonrostro Torralba C, Pallares Arnal V, Herrero Serrano R, Tejero Cabrejas EL, Campillos Maza JM. Delayed-interval delivery in twin pregnancies: report of three cases and literature review. J Matern Fetal Neonatal Med. 2019;32 (2):351-355. doi: 10.1080/14767058.2017.1378336

11 Rodrigues F, Pereira J, Rodrigues T, Montenegro N. [The clinical challenge of delayed interval delivery in multiple pregnancies]. Acta Obstet Ginecol Port. 2015;9(2):148-153. Portuguese

12 Van der Straeten FMA, De Ketelaere K, Temmerman M. Delayed interval delivery in multiple pregnancies. Eur J Obstet Gynecol Reprod Biol. 2001;99(1):85-89. doi: 10.1016/S0301-2115(01) 00376-1

13 Udealor PC, Ezeome IV, Emegoakor FC, Okeke DO, Okere PC. Delayed interval delivery following early loss of the leading twin, case report. Case Rep Obstet Gynecol. 2015;2015:213852. doi: $10.1155 / 2015 / 213852$

14 Centeno M, Clode N, Tuna M, Graça LM. [Delayed delivery perinatal and maternal outcomes]. Acta Obstet Ginecol Port. 2009;3(3):128-133. Portuguese

15 Zhang J, Johnson CD, Hoffman M. Cervical cerclage in delayed interval delivery in a multifetal pregnancy: a review of seven case series. Eur J Obstet Gynecol Reprod Biol. 2003;108(2):126-130. doi: 10.1016/S0301-2115(02)00479-7

16 Eleje GU, Ikechebelu JI, Eke AC, Okam PC, Ezebialu IU, Ilika CP. Cervical cerclage in combination with other treatments for preventing preterm birth in singleton pregnancies. Cochrane Database Syst Rev. 2017; (11):CD012871. doi: 10.1002/14651858.CD012871

17 Cozzolino M, Seravalli V, Masini G, Pasquini L, Di Tommaso M. Delayed-interval delivery in dichorionic twin pregnancies: a single-center experience. Ochsner J. 2015;15(3):248-250. 
18 Doger E, Cakiroglu Y, Ceylan Y, Kole E, Ozkan S, Caliskan E. Obstetric and neonatal outcomes of delayed interval delivery in cerclage and non-cerclage cases: an analysis of 20 multiple pregnancies. J Obstet Gynaecol Res. 2014;40(7):1853-1861. doi: $10.1111 /$ jog.12435

19 Rosbergen M, Vogt HP, Baerts W, et al. Long-term and short-term outcome after delayed-interval delivery in multi-fetal pregnan- cies. Eur J Obstet Gynecol Reprod Biol. 2005;122(1):66-72. doi: 10.1016/j.ejogrb.2004.11.036

20 Graça LM. Medicina materno-fetal. 5. ed. Lisboa: Lidel; 2017

21 Tran PL, Desveaux C, Barau G, Iacobelli S, Boukerrou M. Delayedinterval delivery in multifetal pregnancy: a review and guidelines for management. Gynecol Obstet (Sunnyvale). 2015;5:333. doi: 10.4172/2161-0932.1000333 